\title{
Astronomical Observatory as an identifier of the architectural ensemble of Kazan Imperial University
}

\author{
Khanifa Nadyrova ${ }^{1 *[0000-0002-3163-9355]}$ \\ ${ }^{1}$ Kazan State University of Architecture and Engineering, 420043 Kazan, Russia
}

\begin{abstract}
In the article, the author examines the building of the Astronomical Observatory (1833-1837), which was a part of the architectural ensemble of Kazan Imperial University in the first third of the $19^{\text {th }}$-early $20^{\text {th }}$ centuries (now - Kazan Federal University). The primary purpose of the study is to identify the specific features of the university ensemble. The task is to set the value of the Astronomical Observatory as the basic identifier of the ensemble. The research methodology is based on the theory of identity in architecture and urban planning and the application of a systematic analysis of the ensemble and its components. The author determined the importance of the Astronomical Observatory's building in the university ensemble in the context of the theory of identity. The features of the space-planning solution of the observatory building, its placement in the city landscape, and its great importance in the formation and development of astronomical science in Kazan allow us to conclude that the Astronomical Observatory was one of the identifiers of Kazan Imperial University ensemble. The significance of the research results lies in the development of the theory of identity when one of the objects of the ensemble becomes its identification code.
\end{abstract}

Keywords. Astronomical observatory, architectural ensemble, identity, identifier, historical centre.

\section{Introduction}

The architectural ensemble of Kazan Imperial University, located in the centre of the city, was formed in the 1820-1830s. The ensemble includes the Astronomical Observatory, built in 1833-1837, architect M.P. Korinfsky. Currently, the building of the Astronomical Observatory is nominating for inclusion in UNESCO World Heritage List [1]. In this regard, it is urgent to solve the problem of recognizing the universal value of the Observatory and its role in identifying the architectural ensemble of Kazan Imperial University.

The theory of identity, which has formed over the past decades, focuses on one of the important problems in architecture and urban planning - identifying the identity of both individual buildings and architectural ensembles and urban planning environment. In the generally accepted sense, the identity of an object is determined by its special properties, which make it possible to single out and identify this object in a series of similar or other objects. Initially, the concept of «identity» found a wider distribution and application in the social,

${ }^{*}$ Corresponding author: nadyrova-kh@yandex.ru 
cultural, historical and other humanities. In each of the sciences, the meaning of identity was determined by its research parameters. Studies of the architectural and urban planning environment identity have appeared in [2]. A. Skalkin considers the identity of the urban environment as a naturally formed, holistic, recognizable set of material and intangible features of the urban environment, focused on internal perception, due to the identity with local factors and residents' ideas about their city [3]. The meaning and application of the "identity" term in the architectural and town-planning aspect have been analyzed in detail in foreign studies concerning the historical city. In particular, the following concept of urban identity is formulated: «...the identity of a town is a composition of human lives, cultures, materials, the position of blocks, inner organizations of the plots, etc. Besides, the physical context of a town, formed by climate, topography, rivers, lakes, seas, distribution of animal and plant life, and trees, emphasizes the essential aspect of a town's overall identity. Consequently, identity can be perceived through design, form and colour, the spaces and linkages between buildings and the uses of buildings all of which combine to produce a distinctive spatial and visual quality, helping to distinguish one place from another and create local identity» [4]. At the same time, the existing connection between the city, the events that took place in it, and the memory of them among the residents of the city are emphasized. That is, the identity of the city and its architecture has both material characteristics (the landscape of the city and its parts, architecture and its location, layout, shape, texture, colour, etc.) and intangible characteristics (feelings, memory, memories of people various social groups arising from the city, etc.). Moreover, the composition and characteristics of the physical components of the built environment affect the sense of place perceived and interpreted by people [5].

To understand and appreciate the local originality of the architectural and historical environment of the city, the authors carried out field surveys. The aspects using which people assess the identity of a particular place in the city are investigated. For this, researchers use the questionnaire survey method. This sociological approach is complementary to the definition of urban identity [5].

Researchers are also interested in the importance of the authenticity of objects in determining the identity of the architecture of the city. Concerning the architectural ensemble of Kazan Imperial University, which has existed for almost 180 years, its authenticity will play a significant role in defining identity. "A city's identity is what the insiders (citizens) and outsiders (visitors) perceive, feel and remember about it. Built heritage is one of the most important aspects of the authenticity and subsequently identity of an urban environment. Cities are formed and develop throughout time. They constantly change, develop and transform. Built heritage is the most apparent reflection of this change. It might also include symbolic meanings for the citizens and visitors, often because of the significant historical events associated with it. The buildings and structures of a city tell a story of the past with meanings and cultural values involved. Therefore, built heritage is assumed to be a distinct indicator of urban identity and thus conservation of the built heritage is one of the major concerns in the sustainability of urban identity» [6].

In addition to the above-mentioned aspects of identifying and forming the identity of the historical and architectural environment of the city, there is another one: the urban landscape. Sometimes researchers consider the landscape as one of the identifiers of the lost identity restoration of the urban environment $[7,8]$.

Ensuring the preservation, development and sustainability of the identity of Kazan Imperial University (KSU-KFU) ensemble is an important problem for the city and determine the relevance of this study.

In the study, the author sets the task to identify the identity of the ensemble of Kazan Imperial University in the mid- $19^{\text {th }}$-early $20^{\text {th }}$ centuries. The author isolates its potential identifiers in the form of objects and then establish the identity of each of them to confirm one of them as the primary specific feature of the object. 


\subsection{History of the development of the Kazan Imperial University ensemble}

Kazan Imperial University is a rectangular in plan University campus built up with educational, scientific and auxiliary buildings. It is located in the historical part of Kazan, on the same axis and close to the object of the cultural heritage of global significance the Kazan Kremlin. The axis of the relationship between the two ensembles is the most ancient communication of Kazan - Kremlyovskaya street. The ensemble of Kazan University occupies one of the central quarters of the city, the borders of which are Universitetskaya, and Kremlyovskaya, Astronomicheskaya and Professor Nuzhin streets.

The university ensemble occupies an area with uneven relief. It is situated on the top of a hill with a southwest slope. The border of the ensemble passes at an elevation of 78.0 meters on Kremlevskaya street and along Professor Nuzhin street - lower in relief at an elevation of $64.0 \mathrm{~m}$. The height difference in the opposite boundaries of the territory of the University ensemble is $14.0 \mathrm{~m}$, which is comparable to the height of a five-storey residential building. The Observatory building is situated on a hillside at an elevation of $77.5 \mathrm{~m}$

Teaching astronomy in Kazan began in 1804 when Kazan Imperial University was founded. In 1807, the rector of the university, Yakovkin, developed a project for the university. In 1808-1810 theoretical and practical astronomy was taught to students by Professor I.M.Kh. Bartels from the University of Jena. In 1810, the Austrian professor of astronomy I.I. Littrow was invited to the university. The first observatory of the university located in temporary buildings since 1814. It had a tower for the equatorial, a span for the meridian circle and a retractable roof for small instruments.

In 1820-1822 architect P.G. Pyatnitsky developed a new master plan for the University ensemble. He drew up a project for the complex development of the entire university quarter, linking everything with the main building of the university. The plan provided for an expanded educational facility. The building of the Astronomical Observatory was located behind it. Following this master plan in 1822-1825, designed by architect P.G. Pyatnitsky in Russian classicism style, the Main Academic Building of the university ensemble was built (Fig. 1).

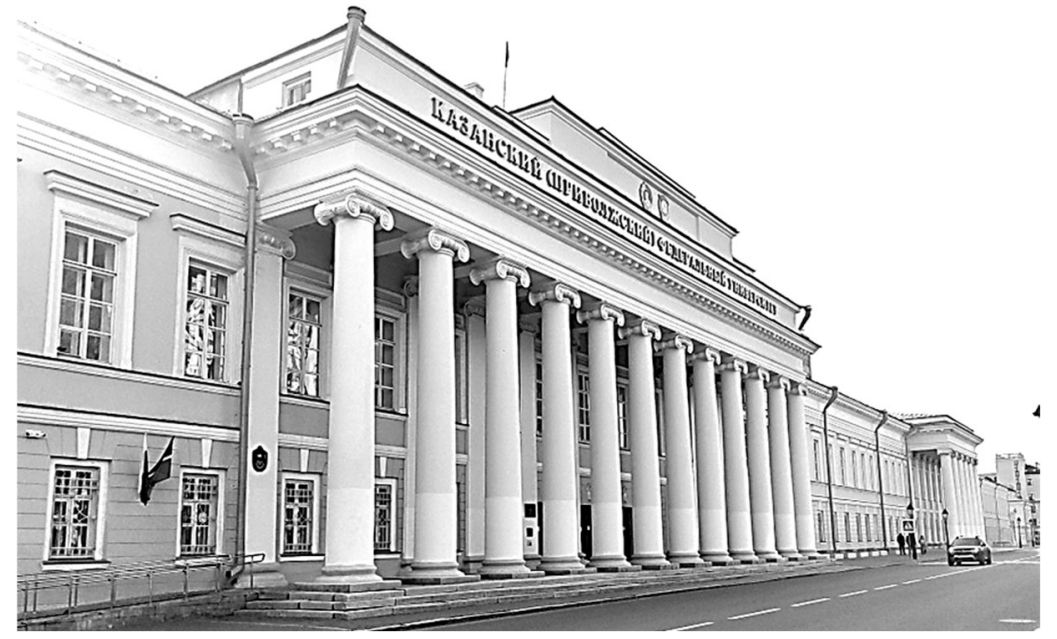

Fig. 1. The Main Academic Building of Kazan Imperial University. Photo by the author.

In 1832, the general plan of the ensemble by P.G. Pyatnitsky was redesigned by the new architect of the university M.P. Korinfsky (Varentsov) along with the rector of the university N.I. Lobachevsky. According to this plan, M.P. Korinfsky brought the building of the Astronomical Observatory to the western part of the complex, and put the building of the Anatomical Theater instead. According to the master plan and the project of M.P. Korinfsky 
in 1836, strictly along the axis of the main building of the university, on the edge of the slope of the Kremlin hill, the Anatomical Theater was erected (Fig. 2). The buildings of the chemical laboratory (1836) and the library (1837), as well as the bathhouse and semicircular outbuildings, were located symmetrically from it. In 1833-1837, the building of the Astronomical Observatory was built, based on the schematic plan of the rector N.I. Lobachevsky (Fig. 3). Such building location was chosen because the sky horizon was free from urban development located below the relief. It ensured a high quality of astronomical observations from the observatory. It is one of the rare examples of the location of an astronomical observatory practically in the centre of the European and Russian city. Therefore, the observatory is sometimes called the city observatory. Comparison of general plans of the University ensemble of architects P.G. Pyatnitsky and M.P. Korinfsky showed that the transfer of the building of the Astronomical Observatory to the western part of the site turned out to be the correct urban planning decision of M.P. Korinfsky.

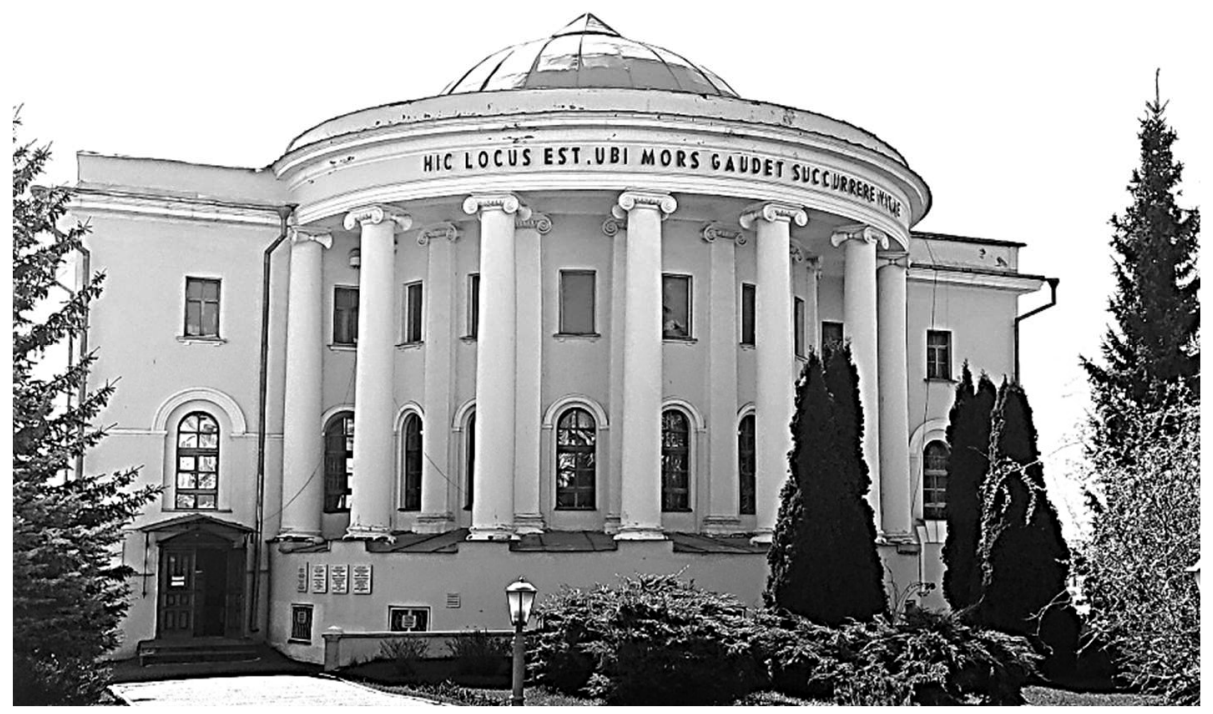

Fig. 2. The Anatomical Theater of Kazan Imperial University. Photo by the author.

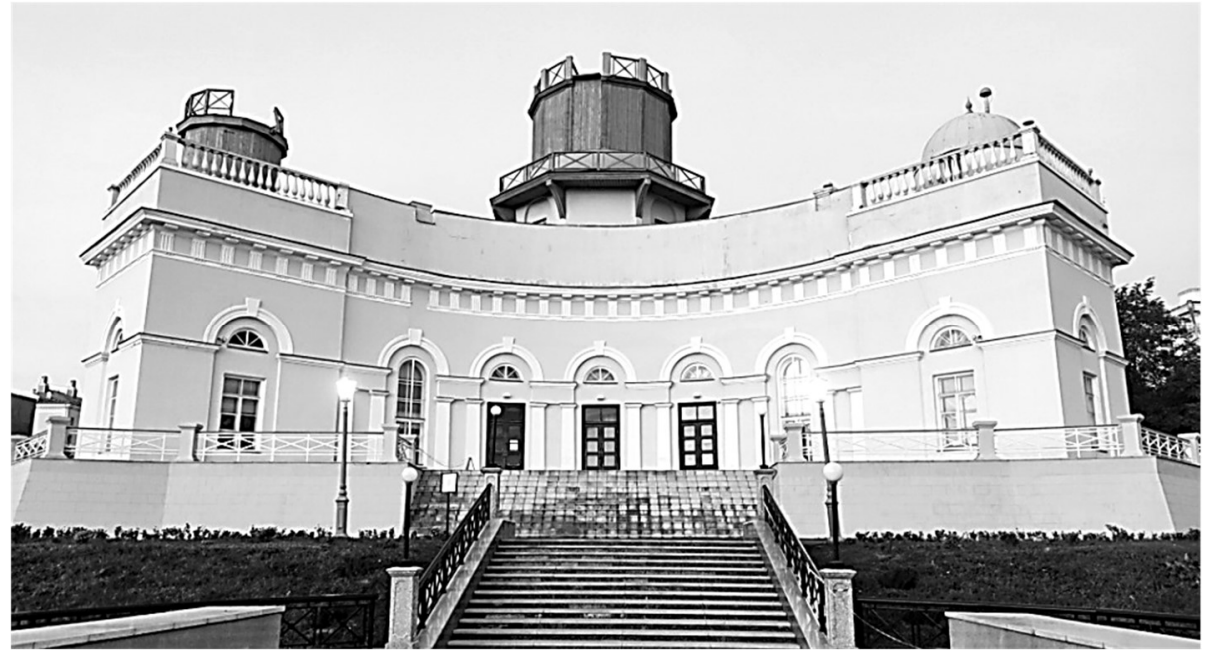

Fig. 3. The Astronomical Observatory of Kazan Imperial University. Photo by the author. 
The building of the Kazan Astronomical Observatory has a symmetrical composition and a complex plan configuration. According to astronomical conditions, the meridian circle did not pass along the main axis of the building, but at an angle of 45 degrees. The main instruments - in the meridian and the first vertical - are placed not along the building axis, as elsewhere, but in a completely unusual way - at an angle of $45^{\circ}$ to the main axis of the building. This led to the peculiarity of the space-planning solution of the observatory. The northeastern part of the building is rectangular. It houses an entrance with a lobby and work areas. The southwestern part of the building is a part of a wide ring with ends protruding beyond the rectangular volume. The main facade of the building, oriented to the southwest, has a semicircular concave shape. In this part of the building, the main hall was located. It was intended to receive visitors and store portable instruments. From the main hall, it was possible to get into the East and West halls, intended for observing the stars. These halls have a cylindrical shape, partly protruding from the side facades of the observatory. The flat roof has three round towers with rotating domes. The central tower with a dome and wooden panelling is installed above the main hall along the longitudinal axis of the building. A wooden balcony on brackets was built around the tower for the refractor telescope. The facades of the building of the Kazan City Observatory are designed in the style of Russian late classicism. A 9-inch refractor, a meridian circle, a heliometer and other astronomical instruments were installed at the observatory. The Kazan Observatory began operating in 1838, that is, a year earlier than the Pulkovo Observatory near St. Petersburg. To decorate the interiors of the observatory premises M.P. Korinfsky developed sketches of furniture and wooden structures for installing tools. A terrible fire in Kazan in 1842 damaged the Astronomical Observatory, as well as other buildings of the university. However, the fire did not destroy the building's supporting structures. The facades and wooden elements of the domes were burnt, which were restored $[9,10]$.

\section{Materials and methods}

To achieve the goal set in the study, in the context of the theory of identity in architecture and urban planning, identification codes (identifiers) are used. They affect the formation and manifestation of identity at the level of a building and an ensemble (city block). The author carried out a systematic analysis of the architectural and planning structure of the university ensemble from the moment of the Emperor Nicholas I decree in 1804 on the establishment of Kazan Imperial University until the middle of the twentieth century. Three objects were identified. They are potential identifiers of the Kazan Imperial University ensemble: the Main Academic Building, the Anatomical Theatre, and the Astronomical Observatory. Each of them was also systematically analyzed. Identification codes (identifiers) of each of them were revealed.

A systematic analysis of the architecture of the Main Academic Building, the Anatomical Theater and the Astronomical Observatory included the study of bibliography, archival materials, field surveys of the architectural ensemble of Kazan Imperial University and its buildings. To reveal the topic of our research, it is necessary to understand the concept of «identification code» or «identifier». Some researchers believe that the identification codes of urban spaces are characteristic features, properties and certain metric parameters by which we recognize certain places in the city and distinguish them from similar places in other cities. Such codes or symbols, identity identifiers can be either individual objects of the architectural environment, or combinations of objects or whole ensembles or clusters. Natural landscape conditions are one of the identifying signs of a place or city as a whole. Along with them, the cultural and historical codes of the place («spirit of the place») can serve as an identification factor of the city environment [11, pp. 133-134]. 
Researchers analyze the role of architecture in shaping the identity of the urban environment and believe that a block, a residential group, a street, a building can act as identifiers (identification codes) of a city. As such, individual buildings or the prevailing diversity of development can reveal the identity of a particular city or settlement. A city is often recognized by one or several buildings that become its symbols, symbols of identity. That is, architecture has the properties to endow the identity of the city and rural settlements, settlements, individual territories [12, pp. 12, 14-15].

Foreign researchers studying the identification codes for the formation of architectural identity, note such factors as spatial organization, temporal (historical) organization, semantic organization, i.e. the figurative and semantic organization of the space that preserves the traditions of a particular place, as well as general design principles, plans and forms of the building, building materials and the relationship with the context of the building [13, p. 106].

The most deeply and systemically historical and theoretical aspect of the identity of the architectural and historical environment at the regional, city, quarter level was studied by T.V. Vavylonsky. He established an identification system (group of identifiers), revealing the quarter (ensemble) identity of the urban environment. This system includes natural landscape, urban planning, architectural and historical, ethnographic, functional, mental, event identifiers [14, P. 31].

Some studies reveal the influence of the system of priority identification codes on a certain type of architecture [15]. Therefore, identification codes, i.e. identifiers affect the identity of an object, ensemble, block, city, and region. However, according to the author, the listed identifiers are not always sufficient for identifying the identity of an object or development of a particular city. Depending on the nature of the city and the objectives of the study, this series can be added to religious, national, etc. identification codes $[16 ; 17]$. Identification codes in architecture and urban planning can change over time, with changing conditions for the development of city architecture, new ones may appear [18, p. 43].

Analysis of bibliographic sources showed that when determining the identity of the architectural and historical environment at the level of a city, quarter, building, researchers distinguish typological groups of identifiers that combine several identification codes. That is, these identifiers help to identify the identity of objects of different levels: region, city, quarter, ensemble, object. However, depending on the level of objects, the list of identifiers (identification codes) can be expanded or reduced and modified. In this study, several identifiers characterizing the identity of the University ensemble were analyzed, and the three above-mentioned objects were identified. The architectural identification system of the ensemble of Kazan Imperial University includes its architectural and urban planning environment as a material component (individual objects of the ensemble) and an intangible environment («spirit of the place»). The system has the following identifiers (identification codes) (according to T.V. Vavylonsky): natural landscape, urban planning (organization of the ensemble within the quarter, architectural and historical (development of the architecture and composition of the ensemble), mental (mentality and value preferences of the faculty and student environment); functional (determined by the functional content of the objects of educational, research, etc. functions); event-driven (determined by important historical events, discoveries and names associated with this ensemble and its objects).

\section{Results}

Table 1 summarizes the identifiers (identification codes) determined for each selected object of the ensemble. 
Table 1. Identifiers of objects of the ensemble of Kazan Imperial University.

\begin{tabular}{|c|c|c|c|c|}
\hline \multirow{2}{*}{ 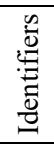 } & & \multicolumn{3}{|c|}{ Objects of the Kazan Imperial University ensemble } \\
\hline & $\begin{array}{l}\text { Identification } \\
\text { codes }\end{array}$ & $\begin{array}{l}\text { Main Academic } \\
\text { Building }\end{array}$ & Anatomical theatre & $\begin{array}{l}\text { Astronomical } \\
\text { observatory }\end{array}$ \\
\hline 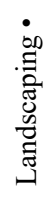 & $\begin{array}{l}\text { - placement on } \\
\text { the site of the } \\
\text { university }\end{array}$ & $\begin{array}{l}\text { The building is located } \\
\text { on a flat surface of the } \\
\text { upper part of the hill }\end{array}$ & $\begin{array}{l}\text { The building is located } \\
\text { on the central axis of } \\
\text { the main building in } \\
\text { the courtyard of the } \\
\text { ensemble on the edge } \\
\text { of the slope of the hill }\end{array}$ & $\begin{array}{l}\text { The building is located in } \\
\text { the western part of the } \\
\text { complex in an open area } \\
\text { on the edge of a hillside }\end{array}$ \\
\hline 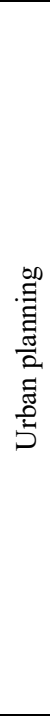 & $\begin{array}{l}\text { - placement in } \\
\text { the planning } \\
\text { structure of the } \\
\text { city, } \\
\text { - organization of } \\
\text { the ensemble } \\
\text { within the } \\
\text { quarter, } \\
\text { - perception of } \\
\text { the object by the } \\
\text { viewer in the } \\
\text { development of } \\
\text { the city. }\end{array}$ & $\begin{array}{l}\text { Placed along the red } \\
\text { line of the north- } \\
\text { eastern border of the } \\
\text { quarter that makes up } \\
\text { the territory of the } \\
\text { ensemble. } \\
\text { The building is } \\
\text { elongated with the } \\
\text { main façade along the } \\
\text { red line of } \\
\text { Kremlyovskaya street. } \\
\text { The viewer perceives } \\
\text { the perspective of } \\
\text { Kremlyovskaya street } \\
\text { from two points (north } \\
\text { and east). From other } \\
\text { points, it is not entirely } \\
\text { perceived. Identified } \\
\text { only near the } \\
\text { alignment of the street }\end{array}$ & $\begin{array}{l}\text { The main façade is } \\
\text { oriented towards the } \\
\text { courtyard façade of the } \\
\text { Main Academic } \\
\text { Building. The side } \\
\text { facades are covered } \\
\text { with utility buildings. } \\
\text { The courtyard façade } \\
\text { is oriented towards the } \\
\text { city. The theatre } \\
\text { building is perceived } \\
\text { by the viewer only } \\
\text { when approaching it } \\
\text { along the courtyard } \\
\text { driveway parallel to } \\
\text { Kremlyovskaya street } \\
\text { because it is located in } \\
\text { the back of the } \\
\text { courtyard }\end{array}$ & $\begin{array}{l}\text { The main façade is oriented } \\
\text { towards the south-western } \\
\text { part of the horizon towards } \\
\text { the suburban part of the city, } \\
\text { rising above it by } 13.5 \mathrm{~m} \text {. } \\
\text { The view is perceived from } \\
\text { the Malo-Posadskaya } \\
\text { (Profsoyuznaya, } \\
\text { Professor Nuzhin), } \\
\text { Astronomicheskaya } \\
\text { streets, from the corner of } \\
\text { the intersection of } \\
\text { Kremlyovskaya and } \\
\text { Astronomicheskaya streets. } \\
\text { On the street panoramas, it } \\
\text { stands out for its } \\
\text { extraordinary completion, } \\
\text { which makes it stand out in } \\
\text { urban development. } \\
\text { Architectural and historical } \\
\text { compositional structure }\end{array}$ \\
\hline 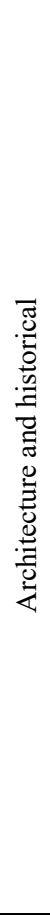 & $\begin{array}{l}\text { - space-planning } \\
\text { structure of the } \\
\text { object } \\
\text { - the style of the } \\
\text { object }\end{array}$ & $\begin{array}{l}\text { The two-storey } \\
\text { building, extended } \\
\text { along the front of } \\
\text { Kremlyovskaya street } \\
\text { with a corridor } \\
\text { planning system. The } \\
\text { main façade is } \\
\text { decorated with a } \\
\text { central and two lateral } \\
\text { porticoes of the Ionic } \\
\text { order. On the } \\
\text { courtyard façade on } \\
\text { the main axis of the } \\
\text { building, the volume } \\
\text { of the assembly hall } \\
\text { with the university } \\
\text { church on the second } \\
\text { floor stands out. } \\
\text { The symmetrical } \\
\text { building is designed in } \\
\text { the style of Russian } \\
\text { classicism. }\end{array}$ & $\begin{array}{l}\text { The building has a } \\
\text { symmetrical-centred } \\
\text { composition. } \\
\text { It is two-storeyed, with } \\
\text { a cylindrical volume } \\
\text { protruding from the } \\
\text { prismatic volume of } \\
\text { the auditorium under } \\
\text { the dome, decorated } \\
\text { along the main façade } \\
\text { with powerful columns } \\
\text { of the Ionic order. }\end{array}$ & $\begin{array}{l}\text { The building of the Kazan } \\
\text { Astronomical } \\
\text { Observatory has a } \\
\text { symmetrical composition } \\
\text { and a complex plan } \\
\text { configuration. According } \\
\text { to the conditions for } \\
\text { conducting astronomical } \\
\text { observations, the main } \\
\text { instruments are not placed } \\
\text { along the axis of the } \\
\text { building, as elsewhere, } \\
\text { but at an angle of } 455^{\circ} \text { to } \\
\text { the main axis of the } \\
\text { building. This led to the } \\
\text { peculiarity of the space- } \\
\text { planning solution of the } \\
\text { observatory. } \\
\text { northeastern part of the } \\
\text { building is rectangular. } \\
\text { The main façade of the } \\
\text { building, oriented to the } \\
\text { southwest, has a } \\
\text { semicircular concave } \\
\text { shape. The flat roof has } \\
\text { three round towers with } \\
\text { rotating domes. }\end{array}$ \\
\hline
\end{tabular}




\begin{tabular}{|c|c|c|c|c|}
\hline 栉 & $\begin{array}{l}\text { - functional content } \\
\text { of the facilities }\end{array}$ & $\begin{array}{l}\text { Academic building } \\
\text { with auditoriums, an } \\
\text { assembly hall and a } \\
\text { church. } \\
\text { Functions: teaching } \\
\text { and educational, } \\
\text { public, } \\
\text { museum }\end{array}$ & $\begin{array}{l}\text { Auditorium for } \\
\text { lectures, preparatory } \\
\text { room, museum of } \\
\text { medical curiosities. } \\
\text { Functions: teaching } \\
\text { and educational, } \\
\text { research, museum }\end{array}$ & $\begin{array}{l}\text { Study rooms, sliding } \\
\text { domes above the rooms } \\
\text { with telescopes for } \\
\text { observing the stars and } \\
\text { planets. } \\
\text { Functions: educational, } \\
\text { research museum }\end{array}$ \\
\hline 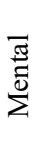 & $\begin{array}{l}\text { - mentality value } \\
\text { preferences }\end{array}$ & $\begin{array}{l}\text { Mentality and value } \\
\text { preferences of the } \\
\text { faculty and student } \\
\text { environment }\end{array}$ & $\begin{array}{l}\text { Mentality and value } \\
\text { preferences of the } \\
\text { faculty and student } \\
\text { environment }\end{array}$ & $\begin{array}{l}\text { Mentality and value } \\
\text { preferences of the faculty } \\
\text { and student environment }\end{array}$ \\
\hline : & $\begin{array}{l}\text { - incidents } \\
\text { discoveries } \\
\text { - events }\end{array}$ & $\begin{array}{l}\text { Fire } 1842 . \\
\text { Gathering of students } \\
\text { with V.I. Ulyanov in } \\
\text { the assembly hall in } \\
1887 . \\
\text { Lobachevsky } \\
\text { discovered non- } \\
\text { Euclidean geometry. }\end{array}$ & $\begin{array}{l}\text { Fire } 1842 . \\
\text { Medical scientist V.S. } \\
\text { Gruzdev at the } \\
\text { beginning of the } \\
\text { twentieth century, the } \\
\text { anatomist P.F. } \\
\text { Lesgaft, physiologist } \\
\text { N.O. Kovalevsky et al. }\end{array}$ & $\begin{array}{l}\text { Fire } 1842 . \\
\text { Outstanding astronomers } \\
\text { carried out observations. } \\
\text { I.M. Simonov in } 1820 \\
\text { participated in an } \\
\text { expedition to Antarctica. } \\
\text { He made discoveries on } \\
\text { magnetism. In 1859, M.A. } \\
\text { Kovalsky proposed a } \\
\text { method for determining the } \\
\text { motion of the Sun in space. }\end{array}$ \\
\hline
\end{tabular}

\section{Discussion}

In this study, the author set the task to establish the value of the Astronomical Observatory as the main identifier of the ensemble. A similar task of establishing identifiers of city buildings and streets was posed by researchers of Samara, Irkutsk, and other cities. Using the example of Irkutsk, the author showed the 8iscovery of the identification features system of the Irkutsk architecture. The author distinguished two forms of architectural identity. The first form, tied to a specific place, represents a certain symbol of the era, the creative idea of an architect, a dominant in the city. The second form of architectural identity arises in the background, street urban development [19]. In this aspect, the ensemble of Kazan Imperial University represents the first form of architectural identity and is emphasized by the unique identity of the Astronomical Observatory. The building of the Kazan Observatory has a unique identity, determined by an extraordinary space-planning solution, verified proportions and a combination of dome-tower finishes typical for this type of structures in the architecture of Russia of the late classicism period. All these components of the Kazan Observatory, combined with the peculiar landscape and urban planning conditions of its placement in the historical environment of a large Russian-Euro-Asian city, are of great importance from the world heritage point of view. The building of the Kazan Astronomical Observatory represents an important stage in the development of the architecture of astronomical structures of the $19^{\text {th }}$ century. It focuses not only on outstanding scientific achievements in the field of astronomical research but also achievements in the development of a special type of compact university observatories in the architectural and stylistic forms of Russian classicism. The compositional structure of the building is solid and monumental, despite the relatively small size of the building.

The set of identifiers, revealing the identity of the main objects of the Kazan University ensemble, is similar to the cult objects of Samara. In this case, the author revealed the influence of the system of identifiers of the architectural and historical environment on the cult architecture of Samara according to the established historical stages of the city's development [20]. The difference is that in our case this set is not considered concerning the stages of the historical development of Kazan, the ensemble of the university and the building 
of the observatory. This is due to the fact that the Astronomical Observatory of the ensemble, like the Main Academic Building and the Anatomical Theater, has retained its authenticity for about 180 years. That is, the ensemble, formed at the end of the first third of the $19^{\text {th }}$ century, practically did not change. The left wing of the Main Academic Building was built at the beginning of the $20^{\text {th }}$ century, is located along the southeastern border of the site and does not affect the overall original composition of the ensemble.

Table 1 presents the identification codes, grouped into identifiers of the main objects of Kazan Imperial University. The analysis of identification codes allows us to assert that among the three analyzed objects that have the potential to become the main architectural identifier of the Kazan Imperial University ensemble, the building of the Astronomical Observatory is. It has the largest viewpoints of disclosure, both in the space of the ensemble itself and in the surrounding urban development. Following the results of this study, in future, it is advisable to consider the university ensemble as one of the architectural identifiers of the historical centre of Kazan in the era of late Russian classicism to study the system of architectural and artistic identity of the city [21].

\section{Conclusions}

1. The ensemble of Kazan Imperial University had three architectural identifiers that reflected its unique identity and originality: the Main Academic Building, the Anatomical Theater and the Astronomical Observatory.

2. The building of the Astronomical Observatory had a unique architectural identity, which was formed by identification codes:

- Landscape and natural (the building was located on the watershed - the crest of the relief of the Kremlin hill, which ensured the elevation of the building above the city's buildings and the opening of the main facade of the observatory to the southwestern part of the horizon to provide astronomical observations).

- Urban planning (the building was a part of an ensemble that occupied an entire city block and was located in its undeveloped part on a terraced area).

- Architectural and historical (The building had a specific compositional and space-planning structure due to the requirements for the functioning of this type buildings. It has a symmetrical composition and a complex plan configuration. According to astronomical conditions, the meridian circle passed not along the main axis of the building, but at an angle of 45 degrees. The main instruments - in the meridian and the first vertical - were placed not along the axis of the building, as elsewhere, but quite unusually, in slots, at an angle of $45^{\circ}$ to the main axis of the building, which led to the peculiarity of the space-planning solution of the observatory. The flat roof in the front part of the building has three round towers with rotating domes).

- Mental and event-driven (University students studied at the observatory, prominent scientists-astronomers of Russia and Western Europe conducted astronomical scientific observations. The building is associated with outstanding discoveries in the field of astronomy).

3. The building of the Astronomical Observatory in the ensemble of Kazan Imperial University played the role of the main architectural identifier. This role was due to the unique identity of the observatory, it's asymmetric, relatively autonomous placement in the space of the university ensemble.

\section{References}

1. R.M. Valeev, R.R. Khairutdinov, Yu.A. Nefedyev, A.G. Sitdikov, R.R. ValeevaKhakimova. Astronomical observatories of Kazan University as a potential UNESCO World Cultural Heritage Site, Heritage and modernity 3 (1), 30-53 (2020). 
2. A.A. Skalkin. The Concept of Identity and Factors of its Formation, Architecture and Modern Information Technologies 4 (41), 57-67 (2017).

3. A.A. Skalkin. Architectural Identity of the City: Concept and Research Methods, Architecture and Modern Information Technologies 2 (43), 87-97 (2018).

4. Mert Nezih Rifaioglu, Neriman Şahin Güçhan. The Concept of Identity and Its Identification Process in Urban Conservation Projects, An International Conference of CSAAR on Regional Architecture and Identity in the Age of Globalization 3, 1099-1111 (2007).

5. J. Ernawati. Dimensions Underlying Place Identity for Sustainable Urban Development, International Journal of Science and Technology 3 3, 271-285 (2018).

6. I. Kaymaz. Urban landscapes and identity, Advances in Landscape Architecture. Edited by Murat Ozyavuz, (2013).

7. A.N. Gushchin, M.N. Divakova. Reconstruction of the identity of the Ural city as a factory city by architectural and landscape reconstruction, Architecture and Design 2 , 23-34 (2019).

8. Kh.G. Nadyrova. The problem of reviving the identity of the architecture of the Old Tatar settlement of Kazan, Historical ethnology. Scientific Journal 4 2, 255-263 (2019).

9. I.M. Simonov. Description of the Kazan University Observatory, Journal. Min. nar. prosv. 7, 1-22 (1838).

10. B.A. Vorontsov-Velyaminov. Part III. The emergence and development of a network of observatories in Russia in the XIX century on the basis of universities, History of Astronomy 369, 102-233 (1956).

11. M. Klammer, N.M. Glebova, I.E. Druzhinina. Identification codes of the architectural environment of urban spaces, Investment. Construction. Realty 7 3, 132-144 (2017).

12. G.V. Esaulov. About identity in architecture and urban planning, Architecture 4, 12-18 (2018).

13. Z. Torabi, S. Brahman. Effective Factors in Shaping the Identity of Architecture, MiddleEast Journal of Scientific Research 15 (1), 106-113 (2013).

14. T.V. Vavilonskaya. Architectural and historical environment of the Samara Volga region: formation, state, concept of sustainable development, The dissertation of the doctor of architecture. Samara, 414 (2017).

15. N.A. Kosenkova, A.A. Serova. Formation of the identity of public objects on the example of Samara, Urban planning and architecture 8 1, 109-116 (2018).

16. Kh.G. Nadyrova. The role of cult architecture in preserving the identity of the architectural and historical environment of Kazan. Formation of the architectural environment of Belarus taking into account traditions and modern trends, Materials of the International Scientific and Practical Conference, 37-38 (2020).

17. Kh.G. Nadyrova, T.V. Vavilonskaya. National identity of the architectural and historical environment of the Tatar villages of the Kazan district of the late XIX-early XX centuries, Izvestiya KGASU 4 (50), (2019).

18. Kh. Truspekova. Architecture of Almaty and issues of identity, Central Asian Journal of Art Studies $13,37-47$ (2016).

19. N.M. Glebova, A.G. Bolshakov. Principles of preservation and formation of architectural identity in the street construction of the historical part of Irkutsk, Izvestiya vuzov. Investment. Construction. Real estate 9 (3), 606-619 (2019).

20. N.A. Kosenkova, A.A. Serova. The impact of the architectural and historical environment on the cult objects of Samara, Urban planning and architecture 83 (32), 93-98 (2018).

21. A.V. Tsorik. Model of architectural and artistic identity of the city, Innovations and investments 3, 314-318 (2021). 